\title{
Strengthening of Self Compacting Concrete Using Ground Granulated Blast Furnace Slag (GGBS) for Cost Efficiency
}

\author{
Pratik Deshmukh \\ Civil Engineering Department, All India Shri Shivaji Memorial Society's College Of Engineering, Pune, India,
}

\begin{abstract}
To improve the concrete composites and its quality with an economical approach there is a need of some material to reused . Hence, this study focus on achieving towering strength concrete by using these Ground Granulated Blast Furnace Slag which is the waste from iron industry. It is obtained from blast Furnace in water or steam by quenching molten iron Slag. GGBS is used to make durable concrete structure in combination with ordinary Portland cement and other materials. Different test are performed and the percentage of the ground granulated blast furnace slag is varied from $20 \%, 30 \%$ and $40 \%$. The percentage increase in the compressive strength at $30 \%$ addition of GGBS is $1.74 \%$. Thus, it can be concluded that maximum compressive strength of self compacting concrete with the combination of admixtures (SP+VMA) may be obtained by adding 30\% GGBS which is a waste material of Iron industry.
\end{abstract}

Keywords: Ground Granulated Blast Furnace Slag (GGBS), Self Compacting Concrete.

\section{Introduction}

In present scenario construction industry, use of concrete is going on increasing speedily. Cement is most important constituent material of the concrete which formed by natural raw material like lime and silica. As these materials are nonrenewable therefore situation may occurs when there will be no lime on earth for production of cement. This situation leads to think all people/researchers working in construction industry to do research work on cement replacing material and options to use it productively. Industrial wastes like Ground Granulated Blast Furnace Slag (GGBS) show chemical properties similar to cement. Use of GGBS as cement replacement will simultaneously reduces cost of concrete [1] and help to reduce rate of cement consumption. Hence, this study focus on achieving towering strength concrete by using these Ground Granulated Blast Furnace Slag which is the waste from iron industry.

The research reported in their study work which aimed to develop a framework for mixture proportions of different materials used for self compacting concrete. In particular two main phases as laboratory phase and plant phase which gives overall idea about how to define different mixes, batches and materials. Masahiro Ouchi [2] has described background and basics of self compacting concrete and its development stages in the proposed study. The investigations of self compacting concrete and different testing method are main focused in the work. These method are then adopted in laboratory for testing of self compacting concrete. It also describes applications of SCC regard with construction sector.

A research work is also done on testing the compressive strength of PCC and concrete with GGBFS [4]. It also defined the amount of GGBFS to be used in percentage to achieve maximum compressive strength. The research work also included different method of mix designing with materials used. Finally concluded with comparison between PCC and PCC with GGBFS and presenting PCC with GGBFS is better option for gaining strength in concrete.

Effort are also made to quantify the strength of ground granulated blast furnace slag (GGBS) at various replacement levels and evaluate its efficiencies in concrete [6]. This research evaluates the strength and efficiency of strengthening factors to harden the concrete, by partially replacing cement by various percentages of ground granulated blast furnace slag for M35 grade of concrete at different ages [3]. From this study, it can be concluded that, since the grain size of GGBS is less than that of ordinary Portland cement. The optimum GGBS replacement as cementation material is regarded by higher compressive strength, lower heat of hydration, resistance to chemical attack, better efficiency, good durability and economic.

"Ground Granulated Blast-Furnace Slag" (GGBFS) is formed following the process for grinding "Granulated Blast Furnace Slag" (GBFS) that is a kind of by product produced via blast furnace operated in our steel works [2]. GGBFS is hydraulic, mixed in other cement products, and utilized as the material for blast furnace cement, soft concrete mixture material, etc. As GGBFS is utilized for such a purpose above, compared with ordinary Portland cement, GGBFS utilization dispenses with the energy consumed to burn limestone and $\mathrm{CO}_{2}$ gas emission from burning fuel and limestone itself coincidently [5]. Therefore, GGBFS is definitely the "globally eco-wise" product.

As GGBFS is mixed in cement products, it increases chemical resistance of concrete, intensity, mobility, and strength over a long term. Moreover, it also enhances a remarkable effect on crack control (exothermic control) and alkali aggregate reaction control. It absolutely suggests that for cement GGBFS is the best partner of all. GGBFS is produced in the site of JFE Steel East (Chiba) and West (Kurashiki) by member manufacturers of JFE group. 


\section{International Journal of Science and Research (IJSR) \\ ISSN (Online): 2319-7064}

Index Copernicus Value (2013): 6.14 $\mid$ Impact Factor (2014): 5.611

\section{Benefits of GGBS in Concrete}

\subsection{Sustainability}

It has been generally stated that the manufacture of one tonne of Portland cement would require approximately 1.5 tonnes of mineral extractions together with a amount of $5000 \mathrm{MJ}$ of energy, and would generate 0.95 tonne of $\mathrm{CO} 2$ equivalent. When GGBS is a by-product of steel manufacturing is done, it is reported that the production of one ton of GGBS would generate only about 0.07 tonnes of $\mathrm{CO} 2$ equivalent and consume only about $1300 \mathrm{MJ}$ of energy [4].

\subsection{Color}

Color of Ground granulated blast furnace slag is off-white. This whiter color is also seen in concrete made with GGBS, especially at replacements superior than 50\% [6]. The additional aesthetically pleasing appearance of GGBS concrete can aid soften the visual impact of large structures for example bridges and retaining walls [9].

\subsection{Setting Times}

The setting time of concrete is influenced by many factors, in particular temperature and water/cement ratio. With GGBS, the setting time will be somewhat extended, perhaps by about 30 minutes. The effect will be more prominent at high levels of GGBS and/or low temperatures [8]. An extended setting time is beneficial in that the concrete will remain workable for longer periods, therefore resulting in fewer joints. This is particularly useful in warm weather.

To check the change in strength of concrete according to the proportional change in the concrete contents number of test have to be conducted. Here in this research work the test included are slump flow test, L box test, Compressive Strength Test, Flexural Strength Test [4] [6] [8].

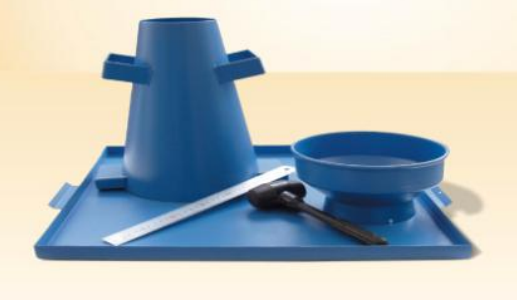

Figure1: Slump flow Test Apparatus

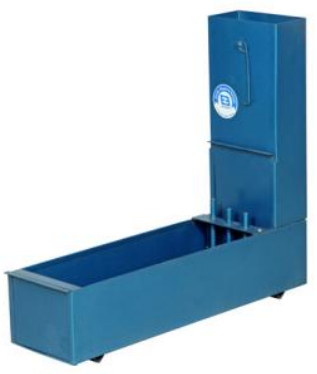

Figure 2: L Box Apparatus

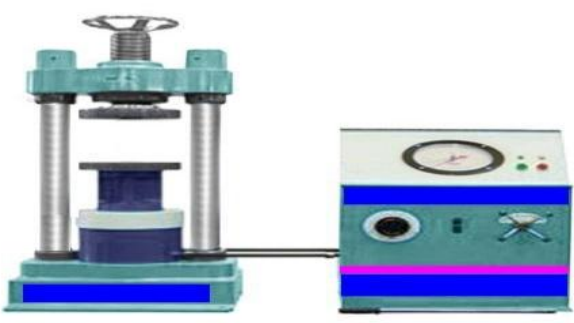

Figure 3: Compression Testing Machine

\section{Results}

\subsection{Test Results Of Self Compacting Concrete Containing GGBS \& The Combination Of Admixtures (SP+VMA)}

The following tables give the test results of effect of addition of GGBS in various percentages on the properties of self compacting concrete containing an admixture combination (SP+VMA)

Compressive strength test results of self compacting concrete containing the combination of admixtures (SP+VMA) with various percentages of GGBS

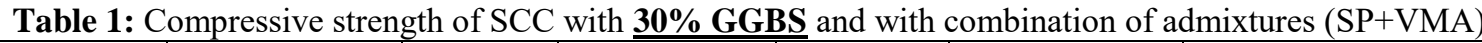

\begin{tabular}{|c|c|c|c|c|c|c|}
\hline $\begin{array}{c}\text { Specimen } \\
\text { Identification }\end{array}$ & $\begin{array}{l}\text { Wt. of Specimen } \\
\text { (N) }\end{array}$ & $\begin{array}{l}\text { Density } \\
\text { (N/cum) }\end{array}$ & $\begin{array}{c}\text { Average density } \\
(\mathrm{N} / \text { cum })\end{array}$ & $\begin{array}{c}\text { Failure Load } \\
(\mathrm{KN})\end{array}$ & $\begin{array}{l}\text { Compressive } \\
\text { Strength (MPa) }\end{array}$ & $\begin{array}{l}\text { Average compressive } \\
\text { strength (MPa) }\end{array}$ \\
\hline $\mathrm{C} 1$ & 82.2 & 24355.5 & \multirow{3}{*}{24177.7} & \begin{tabular}{|l|}
951.75 \\
\end{tabular} & 42.30 & \multirow{3}{*}{41.30} \\
\hline $\mathrm{C} 2$ & 83.8 & 24829.6 & & 900.90 & 40.04 & \\
\hline $\mathrm{C} 3$ & 78.8 & 23348.1 & & 935.55 & 41.58 & \\
\hline
\end{tabular}

Table No.2: Compressive strength of SCC with $\underline{40 \% \text { GGBS }}$ and with combination of admixtures (SP+VMA)

\begin{tabular}{|c|c|c|c|c|c|c|}
\hline $\begin{array}{c}\text { Specimen } \\
\text { Identification }\end{array}$ & $\begin{array}{c}\text { Weight of } \\
\text { specimen }(\mathrm{N})\end{array}$ & $\begin{array}{l}\text { Density } \\
\text { (N/cum) }\end{array}$ & $\begin{array}{l}\text { Average density } \\
\text { (N/cum) }\end{array}$ & $\begin{array}{c}\text { Failure } \\
\text { Load (KN) }\end{array}$ & $\begin{array}{l}\text { Compressive } \\
\text { strength }(\mathrm{MPa})\end{array}$ & $\begin{array}{l}\text { Average compressive } \\
\text { strength }(\mathrm{MPa})\end{array}$ \\
\hline D1 & 84 & 24888.8 & \multirow[t]{3}{*}{24533} & 889.88 & 39.55 & \multirow{3}{*}{39.81} \\
\hline D2 & 81.2 & 24059 & & 900.22 & 40.01 & \\
\hline D3 & 83.4 & 24711.1 & & 897.07 & 39.87 & \\
\hline
\end{tabular}




\section{International Journal of Science and Research (IJSR) \\ ISSN (Online): 2319-7064}

Index Copernicus Value (2013): 6.14 | Impact Factor (2014): 5.611

Overall Results of Compressive Strength

The following table gives the overall results of compressive strength of self compacting concrete containing the combination of admixtures (SP+VMA) for various percentage addition of GGBS

Table 3: Overall Result of Compressive Strength

\begin{tabular}{|c|c|c|}
\hline $\begin{array}{c}\text { Percentage } \\
\text { addition of } \\
G G B S\end{array}$ & $\begin{array}{c}\text { Compressive } \\
\text { strength } \\
(\mathrm{MPa})\end{array}$ & $\begin{array}{c}\text { Percentage increase or decrease of } \\
\text { Compressive strength } \\
\text { w.r.t. ref mix }\end{array}$ \\
\hline $0(\mathrm{Ref})$ & 40.59 & - \\
\hline 20 & 41.20 & +1.50 \\
\hline 30 & 41.30 & +1.74 \\
\hline 40 & 39.81 & -1.92 \\
\hline
\end{tabular}

41.5

39

$0 \% \quad 20 \% \quad 30 \% \quad 40 \%$ PERCENTAGE OF GGBS

Figl e 4: The variation of compressive strength of SCC containing GGBS.

The va ation of compressive strength can be depicted in the form o graph as shown in Figure No. 4

Tensil Strength Test Results Of Self Compacting Concr te Containing The Combination Of Admixtures (SP+V IA) With Various Percentages Of GGBS

Table : Tensile strength of SCC with $\mathbf{3 0 \%}$ GGBS and with combination of admixtures (SP+VMA)

\begin{tabular}{|c|c|c|c|}
\hline $\begin{aligned} \text { Spe } & \text { men } \\
\text { identi } & \text { cation }\end{aligned}$ & $\begin{array}{c}\text { Failure } \\
\text { Load }(\mathrm{KN})\end{array}$ & $\begin{array}{l}\text { Tensile strength } \\
\mathrm{F}=2 \mathrm{P} / \pi d l(\mathrm{MPa})\end{array}$ & $\begin{array}{l}\text { Average tensile } \\
\text { strength }(\mathrm{MPa})\end{array}$ \\
\hline & 330 & 4.66 & \multirow{3}{*}{4.55} \\
\hline & 320 & 4.52 & \\
\hline & 318 & 4.49 & \\
\hline
\end{tabular}

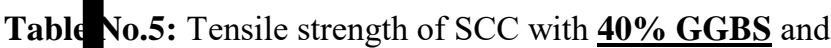
with combination of admixtures (SP+VMA)

\begin{tabular}{|c|c|c|c|}
\hline $\begin{array}{l}\text { imen } \\
\text { ication }\end{array}$ & \begin{tabular}{|c} 
Failure \\
Load (KN)
\end{tabular} & $\begin{array}{c}\text { Tensile strength } \\
\mathrm{F}=2 \mathrm{P} / \pi d \boldsymbol{l}(\mathrm{MPa})\end{array}$ & $\begin{array}{l}\text { Average tensile } \\
\text { strength }(\mathrm{MPa})\end{array}$ \\
\hline 1 & 228 & 3.22 & \multirow{3}{*}{3.33} \\
\hline 2 & 236 & 3.34 & \\
\hline & 242 & 3.42 & \\
\hline
\end{tabular}

Overa Results of Tensile Strength

The fo owing gives the overall results of tensile strength of self ce mpacting concrete containing the combination of admixt res (SP+VMA) for various percentage addition of GGBS
Table 6: Overall Result of tensile Strength

\begin{tabular}{|c|c|c|}
\hline $\begin{array}{c}\text { Percentage } \\
\text { addition of } \\
\text { GGBS }\end{array}$ & $\begin{array}{c}\text { Tensile } \\
\text { strength } \\
(\mathrm{MPa})\end{array}$ & $\begin{array}{c}\text { Percentage increase or decrease } \\
\text { of tensile strength w.r.t. ref mix }\end{array}$ \\
\hline 0 (REF) & 3.34 & - \\
\hline 20 & 3.50 & +4.79 \\
\hline 30 & 4.55 & +36.22 \\
\hline 40 & 3.34 & 0 \\
\hline
\end{tabular}

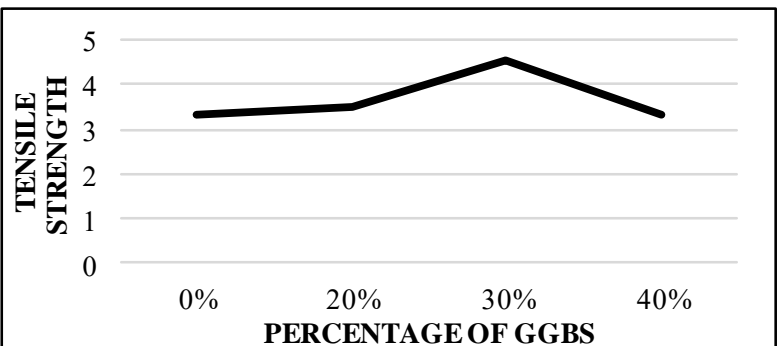

Figure 5: The variation of tensile strength of SCC containing GGBS

The variation of tensile strength can be depicted in the form of graph as shown in SS Figure No. 5

Flexural Strength Test Results Of Self Compacting Concrete Containing The Combination Of Admixtures (SP+VMA) With Various Percentages Of GGBS

Table 7: Flexural strength of SCC with $\underline{\mathbf{3 0 \%} \text { GGBS }}$ and with combination of admixtures (SP+VMA)

\begin{tabular}{|c|c|c|c|}
\hline $\begin{array}{c}\text { Specimen } \\
\text { identification }\end{array}$ & $\begin{array}{c}\text { Failure } \\
\text { Load } \\
(\mathrm{KN})\end{array}$ & $\begin{array}{c}\text { Flexural } \\
\text { strength } \\
\mathrm{F}=\mathrm{PL}_{\mathrm{BD}} \mathrm{BD}^{2}\end{array}$ & $\begin{array}{c}\text { Average tensile } \\
\text { strength (MPa) }\end{array}$ \\
\hline $\mathrm{C} 1$ & 11.4 & 5.70 & \multirow{2}{*}{5} \\
\hline $\mathrm{C} 2$ & 10.8 & 5.40 & \multirow{2}{*}{5.53} \\
\hline $\mathrm{C} 3$ & 11 & 5.50 & \\
\hline
\end{tabular}

Table No.8: Flexural strength of SCC with $\underline{40 \% \text { GGBS }}$ and with combination of admixtures (SP+VMA)

\begin{tabular}{|c|c|c|c|}
\hline $\begin{array}{c}\text { Specimen } \\
\text { identification }\end{array}$ & $\begin{array}{c}\text { Failure } \\
\text { Load (KN) }\end{array}$ & $\begin{array}{c}\text { Flexural } \\
\text { strength } \\
\text { F=PL/BD }\end{array}$ & $\begin{array}{c}\text { Average tensile } \\
\text { strength (MPa) }\end{array}$ \\
\hline D1 & 9.80 & 4.90 & \multirow{2}{*}{4} \\
\hline D2 & 10.30 & 5.15 & \multirow{2}{*}{4.92} \\
\hline D3 & 9.40 & 4.70 & \\
\hline
\end{tabular}

\section{Overall Results of Flexural Strength}

The following table gives the overall results of flexural strength of self compacting concrete containing the combination of admixtures (SP+VMA) for various percentage addition of GGBS

Table No.9: Overall Result of flexural Strength

\begin{tabular}{|c|c|c|}
\hline $\begin{array}{c}\text { Percentage } \\
\text { addition of GGBS }\end{array}$ & $\begin{array}{c}\text { Flexural } \\
\text { strength }(\mathrm{MPa})\end{array}$ & $\begin{array}{c}\text { Percentage increase or } \\
\text { decrease of tensile } \\
\text { strength } \text { w.r.t. ref. mix }\end{array}$ \\
\hline 0 (Ref.) & 5.12 & - \\
\hline 20 & 5.19 & +1.367 \\
\hline 30 & 5.53 & +8.01 \\
\hline 40 & 4.93 & -3.85 \\
\hline
\end{tabular}




\section{International Journal of Science and Research (IJSR)}

ISSN (Online): 2319-7064

Index Copernicus Value (2013): 6.14 | Impact Factor (2014): 5.611

5.6

\section{2}

\section{$0 \% \quad 20 \% \quad 30 \% \quad 40 \%$}

PERCENTAGE OF GGBS

Figu 6: The variation of flexural strength of SCC containing GGBS

\subsection{Flow est Result Of GGBS}

The follo ing tables give the flow test results of effect of addition o red mud in various percentages on the properties of self combinati mpacting concrete containing an admixtures of (SP+VMA)

Table 10: Slump flow test results

\begin{tabular}{|c|c|c|c|}
\hline Percentag & of GGBS & Slump flow (mm) & Time in sec $\mathrm{T}_{50}$ \\
\hline & & 690 & 4.70 \\
\hline & & 710 & 4.60 \\
\hline & & 730 & 4.67 \\
\hline & & 720 & 4.62 \\
\hline
\end{tabular}

Table 11: L box test result

\begin{tabular}{|c|c|c|c|c|c|}
\hline $\begin{array}{r}\text { Percentag } \\
\text { of GGBS }\end{array}$ & $\begin{array}{c}\text { Height } \\
\text { H1 }\end{array}$ & $\begin{array}{c}\text { Height } \\
\text { H2 }\end{array}$ & H2/HI & $\begin{array}{c}\text { Time taken to } \\
\text { reach 200mm }\end{array}$ & $\begin{array}{c}\text { Time taken to } \\
\text { reach 400mm }\end{array}$ \\
\hline 0 & 85 & 75 & 0.88 & 9.24 & 15.8 \\
\hline 20 & 75 & 62 & 0.83 & 6.30 & 10.2 \\
\hline 30 & 80 & 77 & 0.96 & 3.80 & 6.5 \\
\hline 40 & 70 & 63 & 0.60 & 4.60 & 8.8 \\
\hline
\end{tabular}

\section{Conc ision}

It has bee observed that the compressive strength of self compactin admixture addition 0 concrete produced with the combination of such as (SP+VMA) goes on increasing upto $30 \%$ GGBS.

After 40\% Iddition of GGBS, the compressive strength starts decreasing i.e. the compressive strength of self compacting concrete 1 oduced with (SP+VMA) is maximum i.e 41.30 Mpa when $0 \%$ GGBS is added.

The perce fage increase in the compressive strength at $30 \%$ maximum ompressive strength of self compacting concrete with the ombination of admixtures (SP+VMA) may be obtained $b$ adding 30\% GGBS which is a waste material of Iron indus $\mathrm{y}$.

From the pove experimental results, it is proved that GGBS can be us as an alternative material for cement, reducing cement co sumption and reducing the cost of construction. Use of industrar wast proutues saves tri cirvirvirmert ant addition o GGBS is $1.74 \%$. Thus, it can be concluded that

\section{References}

[1] Mohammad Vahdani, Iman Mehdipour \& Saeed Yousefi, 'Effect Of Viscosity Modifying Admixtures On The Rheological Properties And Stability Of Self Consolidating Cementitious Materials' 35th Conference on OUR WORLD IN CONCRETE \& STRUCTURES: 25 - 27 August 2010, Singapore.

[2] Umar A. And Al-Tamimi, 'Influence of Viscosity Modifying Admixture (VMA) on the Properties of SCC Produced Using Locally Supplied Materials in Bahrain' Jordan Journal of Civil Engineering, Volume 5, No. 1, 2011 Page No. 32.

[3] Rudraswamy M.P. And Dr. K. B. Prakash, 'An Experimental Investigation On The Effect Of Alternate Wetting And Drying On The Properties Of Concrete Produced By Red Mud' ISSN 2320-5407International Journal of Advanced Research (2014), Volume 2, Issue 1, Page No. 473-484.

[4] Thavasumony D, Thanappan Subash, Sheeba D., 'High Strength Concrete using Ground Granulated Blast Furnace Slag (GGBS)' International Journal of Scientific \& Engineering Research, Volume 5, Issue 7, July-2014 ISSN 2229-5518 Page No. 1050

[5] Manjur A.Shendure1, Mohit Uphade \& Gagan Chajjed, 'Self Compacting Concrete Using Neutralized Red Mud', International Journal of Innovative and Emerging Research in Engineering Volume 2, Issue 2, 2015 eISSN: 2394 - 3343 pISSN: 2394 - 5494.

[6] S. Arivalagan, 'Sustainable Studies on Concrete with GGBS As a Replacement Material in Cement' Jordan Journal of Civil Engineering, Volume 8, No. 3, 2014 Page No. 263.

[7] Kiran K. Shetty, Gopinatha Nayak, Vipul Vijayan, 'Use Of Red Mud And Iron Tailings In Self-Compacting Concrete', IJRET: International Journal of Research in Engineering and Technology eISSN: 2319-1163 pISSN: 2321-7308 Volume: 03 Issue: 06 Jun-2014, Page No. 111.

[8] A.B. Sawant, M. B. Kumthekar \& S. G. Sawant, 'Utilization of Neutralized Red Mud (Industrial Waste) in Concrete', International Journal of Inventive Engineering and Sciences (IJIES) ISSN: 2319-9598, Volume-1, Issue-2, January 2013 Page No. 9.

[9] Muddapu Swaroopa Rani, 'Behaviour Of Self Compacting Concrete Made With GGBS And RHA Under Axial Compression And Flexure' Research and Development Cell Jawaharlal Nehru Technological University Hyderabad - 500 085, A.P., INDIA January 2011.

[10] Celik Ozyildirim, D. Stephen Lane, 'Final Report Evaluation Of Self-Consolidating Concrete' Virginia Transportation Research Council. In Cooperation with the U.S. Department of Transportation Federal Highway Administration Charlottesville, Virginia June 2003 VTRC 03-R13.

[11] EFNARC 'Specification and Guidelines for SelfCompacting Concrete' February 2002 EFNARC, 


\section{Author Profile}

Pratik Deshmukh has received the Bachelors Of Engineering (B.E.) degree in Civil Engineering from All India Shri Shivaji Memorial Society's College of Engineering, Savitribai Phule, Pune University, Pune, During 2011-2015. He has been Excellent student of college at academics and Research work. His area of interest is Construction Management in Civil Engineering. 